\title{
Study of Religious Philosophy on Tapa Brata (Javanese Asceticism Practice) to Overcome the Social Anxiety During COVID-19 Pandemic Era
}

\author{
John Abraham Ziswan Suryosumunar \\ Institut Agama Hindu Negeri Gde Pudja Mataram \\ suryosumunaro202@gmail.com
}

\begin{abstract}
Abstrak
Pandemi COVID-19 yang merupakan bencana global memiliki pengaruh terhadap seluruh aspek kehidupan masyarakat dunia. Indonesia menjadi salah satu negara yang memiliki tingkat penularan COVID-19 yang tinggi, hal tersebut berpengaruh terhadap berbagai kebijakan penanggulangan dalam menekan angka penularan dengan pembatasan mobilitas sosial. Di tengah pandemi ini, masyarakat dihadapkan pada kondisi yang tak kunjung pasti yang mengakibatkan tingkat kebosanan, ketakutan, bahkan kecemasan masyarakat meningkat. Peneliti tertarik untuk mendalami realitas di masa pandemi COVID19 tersebut dengan melihat bahwa terdapat hubungan antara kecemasan masyarakat di masa pandemi COVID-19 ini dengan kesadaran terhadap kebutuhan spiritualitas dalam menghadapi berbagai perubahan yang terjadi. Dengan menggunakan metode hermeneutika filosofis, penelitian kualitatif ini dilakukan dengan berusaha membahas salah satu praktik spiritual dari masyarakat Jawa, yaitu tapa brata, dan menghubungkannya dengan kecemasan masyarakat yang terjadi pada masa pandemi COVID-19. Hasil dari pembahasan yang dilakukan yaitu: (1) kecemasan dalam masyarakat pada masa pandemi diakibatkan oleh kesadaran tentang realitas yang tidak pasti dan senantiasa berubah. (2) Tapa brata adalah laku batin dalam membentuk diri yang tenang dan bijak dalam menerima segala perubahan. (3) Tapa brata adalah laku batin yang bersifat personal dan dapat menanggulangi kecemasan masyarakat di masa pandemi dan berpengaruh secara fisiologis dalam meningkatkan imunitas di masa pandemic COVID-19.
\end{abstract}

Kata Kunci: COVID-19, Kecemasan, Spiritualitas, Tapa Brata 


\begin{abstract}
The COVID-19 pandemic, which is global disaster, has an impact on all aspects of human life. Indonesia is one of the countries that has a high rate of COVID19 transmission, this has an effect on various policies in suppressing transmission rates by limiting social mobility. In the midst of this pandemic, people are faced with uncertain conditions that result in levels boredom, fear and even public anxiety increased. The author is interested in exploring the realities of the COVID-19 pandemic by seeing that there is a relationship between public anxiety during the COVID-19 pandemic and awareness of the need for spirituality in facing the various changes that have occurred. Using the philosophical hermeneutic method, this qualitative research was conducted by trying to discuss one of the spiritual practices of Javanese society, namely Tapa Brata, and to relate it to public anxiety that occurred during the COVID-19 pandemic. The results of the discussion carried out are: (1) anxiety in the people during the pandemic period is caused by awareness of an uncertain and constantly changing reality. (2) Tapa brata is the mental practice of forming a self that is calm and wise in accepting all changes. (3) Tapa brata is an inner practice that is personal and can overcome public anxiety during a pandemic and has a physiological effect in increasing immunity during the Covid-19 pandemic.
\end{abstract}

Keywords: Anxiety, COVID-19, Spirituality, Tapa Brata

\title{
Introduction
}

During the Corona pandemic, or which is often called COVID19 (Corona Virus Disease), that is happening nowadays, there are various life practices that get adjustments to physical distancing policies, PSBB (LargeScale Social Restrictions), and PPKM (Enforcement of Restrictions on Social Activities) in several cities in Indonesia as an effort to deal with the transmission of the virus. This is related to restrictions on various life practices that have the potential to form large-scale crowds, even to the point is to stay at home for certain areas in Indonesia. All activities like educational process, the economy, matters related to traditions, and religious practices are also not free from these adjustments. Whereas various life practices often become habits and are even understood as obligations that must be fulfilled based on social, individual, economic and religious needs.

The existence of this pandemic also has an effect on adjusting and even limiting various economic movements with the closure of various shopping centers, closure of tourist attractions, work from home policies, the occurrence of layoffs by various companies which even in 2020 has reached 6.4 million Indonesian workers (http://republika.co.id). Indirectly this has an impact on the chaos of the economy of every country in the world, because the economic bases are lame and even paralyzed in order to prevent the spread 
of COVID-19. A dilemma condition that showing such enormous impact of pandemic on the movement of life of every human being in the world. The large impact of the Corona virus disease in these conditions can be said to have not only endangered the physical health of the world society, but with various changes during this pandemic, many factors then affect the psychological health of each individual, such as an increasingly heavier economic burden, anxiety from society because the end of the pandemic period that cannot be ascertained, also with fear due to continuous coverage by the mass media. In addition, the most visible impact of the physical distancing policy is the boredom and loneliness experienced by the majority of people. Everyone feels bored and impatient by questioning when this pandemic will end, but ready or not the whole world society is faced with uncertain conditions which require the existence of a new normality and lead to changes in various aspects of human life. It is in this condition that humans need clarity of mind to avoid anxiety and even frustration due to rapid changes

The spirituality of religion and the various beliefs in local traditions have contributed to this, fulfilling various inequalities in the inner dimension of the human being. In this case the author tries to understand one of the spiritual practices of Kejawen which is in line with the physical distancing policy, namely Tapa Brata. According to Endraswara (2011) Kejawen is a local wisdom of Javanese people whose teachings not only touch physical dimension, but more deeply into the spiritual dimension (inner self) in the human relationship with God. In this case, Tapa Brata becomes one of the teachings of Kejawen, which focuses on inner cultivation and mental tranquility to achieve a new awareness of reality. The author's efforts to explore the teachings of Tapa Brata will be correlated with the actual reality in society that occurred during the COVID-19 pandemic.

The author tries to understand the extent to which conditions during the pandemic have provided encouragement or motivation to carry out spiritual practices, such as Tapa Brata, in avoiding frustration or anxiety during the Corona pandemic. The author tries to answer the formulation of the problem using the perspective of religious philosophy. Which the studies of religious philosophy will try to understand religious practice by placing the human position as a whole, both from the physical and non-physical dimensions. In touching these non-physical (mental) aspects, the author will mention some explanations of psychiatric theory which will refer to 
discussions about human motivation to carry out life practices, one of which is religious practice or belief. The underlying motivation must be different from one individual to another, which of course is based on the diversity of experiences by each individual. According to Dister (1996), the impulse of human action itself refers to two bases, namely consciousness and unconsciousness. Based on this framework, the authors conducted this research with the hope of finding a correlation between physical and non-physical needs on the practice of human spirituality, as well as how the teachings of Tapa Brata can have an effect in fulfilling the impulses in humans both based on consciousness and unconsciousness during the Corona pandemic.

\section{Method}

This paper is a qualitative research in the study of religious philosophy. This material is divided into two, primary data and secondary data. The primary data are from some litterateurs sources, Filsafat Agama: Wisata Pemikiran dan Kepercayaan Manusia; Anxiety: Theory, Research and Intervention in Clinical and Health Psychology; Suluk Sopanalaya which is a Javanese literature; Serat Wedhatama which is a Javanese; Salah Satu Sikap Hidup Orang Jawa; Falsafah Hidup Jawa:Menggali Mutiara Kebijakan dari Intisari Filsafat Kejawen. There is supporting data as secondary data in this study which comes from books and journals related to religious philosophy and the focus of discussion, that are anxiety during the COVID-19 pandemic and also spiritual practice of Tapa Brata .

This research is worked by using philosophical hermeneutic method. The author tries to analyze the relationship of anxiety in times of pandemic COVID-19 and a boost to the awareness of spiritual needs, which one of them is through the inner asceticism that is Tapa Brata. According to Anton Baker, there are some methodical elements of philosophical hermeneutic method (Bakker, 2004). Description, describes historically and in detail about the occurrence of anxiety in the society during the COVID-19 pandemic. Then explain what is called Tapa Brata spiritual practice. Interpretation, defines the problems that occur in the context of anxiety during the COVID-19 pandemic and the spiritual needs of the community. Holistic, comprehensively understand the various aspects that become references. Reflection, expressing the possibility of Tapa Brata 
spiritual practice as a solution in controlling anxiety during the COVID-19 pandemic, this reflection is systematic-reflective.

\section{Scope of Religious Philosophy}

Philosophy is an investigation into the essence of everything that exists and may exist through human minds (Poedjawijatna, 1980). In this case, philosophy as a critical, radical, and comprehensive study has a broad range of discussions on all reality, including religion and various religious practices as part of the aspects of human life. Religion, of course cannot be separated from the development of human civilization, especially in relation to human beliefs and relationship to the divine essence. In other words, talking about religion will never escape the discussion about the development of human life itself, which religion in this case can be understood as a system of belief and practice carried out as a way of human life, both physically and mentally (Gazalba, 1979). From this understanding, religion and the context of human development must undergo a process that is always dialogical in line with changes and the context of the problems faced by humans. In this case, the religious philosophy acts as a study that seeks to understand the basics of human spiritual beliefs of the divine nature, including religious practices and the underlying motivations by being exposed to contextual developments that occur.

The role of religious philosophy is to integrate the various beliefs and practices of their beliefs with the development of human life, one of which is science. The relationship between religion and science is often understood as conflicting binary oppositions. This can be seen in the history of the development of science in the Western world, such as in the Middle Ages where religious authorities only placed science as supporting the truth found in the holy scriptures (Muntasyir \& Munir, 2001). At that time, the Western world was dominated by religious dogmas, which concentrated only a single truth and made no room for the truth of science. This condition then triggered the emergence of a conflict between religion and science which led to various claims by scientists against religious authorities marked by the existence of the modern century. At that time, truth was emphasized on the positivist nature of scientific arrogance. The conflict that occurs between religion and science in the Western world can be said to be a conflict between scientific materialism and biblical literalism (Maimun, 2015). Where both have their respective claims to the foundation and source of truth. In other words, the 
effort to reconcile religion and science is an important effort to achieve a holistic understanding. This comprehensive study is then offered in the religious philosophy, which places science and religion both having advantages and disadvantages, but both are seen as recognized sources of truth. In addition, the understanding of religion is directed at esoteric and esoteric approaches. Esoteric is understood as an approach that highlights the formal aspects of a particular religion or belief (Ikbal, 2015), whereas esoteric is more about the approach to spiritual aspects, inner insight, and religious essence. In this case the philosophy of religion provides space for various beliefs that are not only based on formal ties, but also which are forms of spirituality in human religiosity. The bases for this comprehensive understanding of religious philosophy is used by the author to examine more deeply the religious aspects of society, both esoteric and esoteric, based on contextual problems related to the spiritual needs of people's lives during the COVID-19 pandemic.

\section{Mental Problems and Anxiety during COVID-19 Pandemic Era}

When dealing with cases of Corona virus disease transmission, of course, many people, even medical personnel, understand that this virus does not attack nerve function or even mental stability. Basically the Corona virus is contagious and infects the respiratory tract of humans which affects the decrease in body immunity. But if we try to understand its impact more deeply, the existence of this pandemic cannot only be said to be limited to its effects on the condition of physical organs. But furthermore it can have an effect on causing fear or even anxiety that is so basic in the community because of the large number of infections that occur throughout the world, including in Indonesia.

The number of transmission numbers is so large, which is based on data from the Indonesian government on Thursday, 21 May 2020, in just 24 hours there were 973 new cases of COVID-19 transmission, and this figure adds to the number of infected cases throughout Indonesia to 20,162 cases (https: //nasional.kompas.com). From the previous data, not only has become a record for the highest cases of transmission in Indonesia, but has also exacerbated public anxiety about the transmission of the outbreak. Then in early 2021, the number of cases of COVID-19 transmission soared so high. Based on data obtained from John Hopkins University and Medicine (https://coronavirus.jhu.edu), the number of cases of COVID-19 transmission 
in Indonesia has reached $1,147,010$ cases with a death rate of 31,393 . This figure indicates that the spike in cases of COVID-19 transmission in Indonesia is the highest among ASEAN countries. This has resulted in the instability of government policies and various policy changes that inevitably have a direct impact on the confusion, fear and anxiety of the Indonesian people.

The policy for limiting social interaction, both PSBB, is carried out in 2020 then PKKM in 2021 which is basically a limitation of people activities by switching daily routines outside the home to various activities carried out inside the home, like the educational process, work, and other routines. This has had a direct effect on the movement of people's lives. Not only the economy, more in also affects the mental problem of the people, boredom of a large part of society then becomes a phenomenon that most inevitable.

Boredom is a true nature of human beings, which, according to Fromm, existentially, mankind is the one thing that can get stuck in boredom and it was the one that sets it apart from other creatures (Fromm, 1996). In modern human life, it is boredom that has been trying for years to be avoided by working and carrying out its routines. During this pandemic, almost all people in the world feel bored and can't wait with question when the pandemic will end, when can the routines of life be carried out normally again as before, everyone experiences boredom because for months they have been forced to feel situations outside their habits.

But aren't we often said that work routines cause boredom? Even the various entertainment that is served by the media industry is also often considered to cause boredom. This pandemic period is so different because everyone feels an extraordinary passive in himself. Every person confined themselves to activity in the home and attempted to hoard various items need to deal with the pandemic were not sure when it expires. When human became passive, humans are not clicking himself actively with the world, and was forced to give up on the various demands. And it is in this case that humans feel helpless, lonely and restless (Fromm, 1996). Passivity is the result of man to feel anxiety, a feeling alienated from her life, because the bonding social routines rooted in his life. Humans always crave meetings, where with these meetings, humans are able to actualize themselves in a certain benefit to others, and vice versa also benefit from their relationships with other people. 
This social anxiety that is understood in psychology as a disorder. Anxiety, according to Edelmann (1992), is apprehension, tension, or uneasiness which stems from the anticipation of danger, the source of which is largely unknown or unrecognized. From this understanding, it can be explained that this anxiety is uneasiness caused by something that is considered threatening but often it is not really clearly known. Meanwhile, according to Syamsu Yusuf, anxiety is a form of neurotic helplessness, insecurity, and a sense of inability to face a certain reality which is often related to stress in everyday life (Yusuf, 2009). As a neurotic helplessness, anxiety symptoms lead to a tendency for a person's reactivity in the form of fear, worry, or other emotional reactions to small things that happen in his life. It is not uncommon for this condition to cause what is known as frustration. From both these term can be taken a common thread that anxiety always carrying a reactive process in the form of fear and uneasiness on a danger that possible to be faced, there is often the feeling is caused by a variety of things that happen in daily life.

Anxiety during the COVID-19 pandemic is basically not just happen because of a sense of community threatened against transmission of the virus or due to economic pressures as a result of its various bases crippled economy after implementation of PSBB policy, physical distancing, or PPKM in early 2021, but farther caused by a condition of uncertainty. In this case, we can use Heidegger view that distinguished between fear (Furcht) and anxiety (Angst). Anxiety is something that dip to the awareness of the uncertainty, the object of anxiety is really a matter of indeterminate (Hardiman, 2016). It can be understood that what happened during this pandemic period was not only up to people's fear, but furthermore there was a process of anxiety about the position of human being who were in an uncertain reality. An awareness of a throwing into the reality of uncertainty that will continue to be faced by humans that occurred from the beginning of human civilization with various uncertain changes. This pandemic period is one of the triggers for this awareness, due to changes that immediately occur and it is uncertain when it will end and return to normalcy.

The mental condition during the pandemic is basically inseparable from the existence of a reality outside of human power, where the human self in this case feels a throw (dasein) in which he becomes a passive object that is unable to overcome the reality that surrounds his existence. Heidegger explains that this kind of mood is an anxiety which he called 
grundbefindlichkeit (Hardiman, 2016), a feeling that is fundamental and primordial. During this pandemic, every human being learn that life is an uncertain thing. The economy suddenly experienced chaos, the various routines that had been carried out for decades suddenly changed, social activities requiring new orders, and various new habits that were now a proper thing to do, were the impact of the existence of this pandemic. It is this uncertain reality that in Heidegger's view is considered a myth that is incomprehensible by humans (Kristiatmo, 2010). And this is it, the uncertainty of that reality which then demands that humans have selfopenness to all reality though it is opposite from themselves, one of which is through the path of spirituality.

\section{The Concept of Spirituality in Javanese Tradition}

Java is one of the tribes whose their existence is widespread throughout Indonesia, even to several countries in other parts of the world. Its ability to adapt to the environment around it is a positive value which then enables the tribe to settle and develop in various areas. Besides that, the Javanese are also known to have toughness in spirituality. According to De Jonge (1976), spirituality is a part of human being that correlates with divine things and becomes a manifestation of true reality. With base on that point, the discussion of Javanese society can not be separated from efforts to understand the dimensions of spirituality.

The narima (acceptance) and sumarah (openness) attitudes are characteristics of an inner attitude that is identical to the spirituality of the Javanese people which is often referred to as Kejawen. Kejawen itself is a teaching that has been developed from generation to generation in Javanese tribal communities. According to Koentjaraningrat (1984), Kejawen relies on a form of syncretism which was initially carried out by the Wali (Islamic Guardians) and followed by the poets and scholars of Mataram palace as a form of cultural syncretism strategy. As a form of syncretism, Kejawen teachings go through a process of acceptance and openness to various religions and beliefs that influence it. In other words, this view of Kejawen does not refer to one particular formal religion, but tends to combine various teachings to achieve balance and harmony. This is also reinforced by the research of Niels Mulder (1980), that the goal of Kejawen is to overcome religious differences and harmonize oneself to achieve unity in life. 
The essence of Kejawen teachings is the harmony and unity of life. Where this harmony is made clear by the existence of the concept of the unity of the macro and micro cosmos or which is called jagad gede (the big universe) and jagad cilik (the little universes) (Puspaningrat, 1996). In this teaching, human life is always seen as closely related to its relationship with the universe and God as kemanunggalan (a cosmic unity). This harmony then inspires every ideal teaching and principle in the life of Javanese people. Which harmony is not only seen in the combination of the big universe and the little universe, but it's also further linked in laku batin (mental practice). Where this spiritual foundation, according to (Laksono, 2009), leads to the achievement of a condition called tata tentrem (the peaceful system). The concept of the peaceful system is basically an inner attitude that influences the patterns of social life that are formed in the life of Javanese people.

The relationship between spirituality and social life is not only related to the relationship between Javanese people but also to other ethnic groups. This is what emphasizes the self-disclosure of the Javanese people, who do not see life as an arena for competition, but rather as an effort to achieve memayu hayuning bawana (do good to the world), that is the safety and harmony of nature purposes (Endraswara, 2003). This life orientation is that explains why Javanese people can easily adapt to environment and whatever conditions they face. This is also related to the inner attitude of the Javanese people in understanding religion and spirituality.

Picture 1. Javanese culture in some ritual of religions

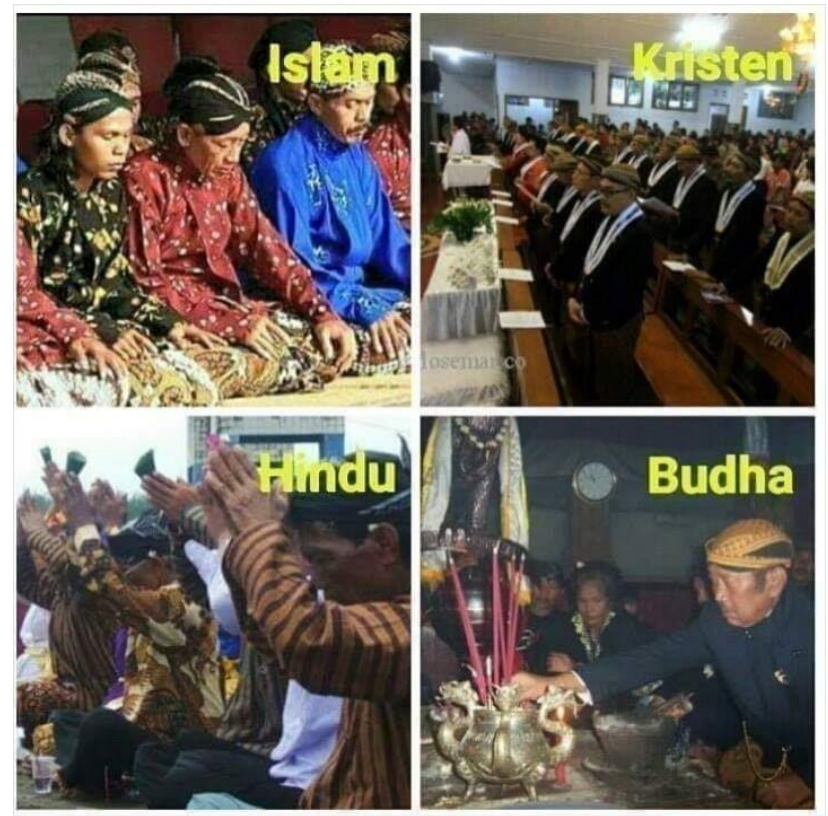


This picture reveals that Javanese people are never identified their culture with any religion, as is the case with several other ethnicities who tend to make their culture as a religious symbol. In this case, it does not mean that Kejawen teachings are against religious principles which tend to be dogmatic. But this Kejawen teaching is accommodative, in the sense that it can adapt and accept various points of view, therefore Javanese culture is capable of being an expression of any religion and belief in line with the realities of life experienced by Javanese society.

\section{Practice of Tapa Brata (Asceticism) in Kejawen Teachings}

One part of Kejawen teachings is Tapa Brata. That Tapa Brata is a asceticism practice that commonly practiced by the Javanese people. The tradition of asceticism in Javanese society basically originates from a syncretic process between Hinduism and Javanese local wisdom that is also related with Sufism in Islamic tradition. To understand the meaning of Tapa Brata from Hinduism, it can be found in the Wrehaspati Tattwa I. 25, and Reg Weda XII. 1, that tapa is defined as self-control by suppressing and managing worldly desires with a good pattern, and brata is defined as human behavior or attitude (Sutarti, 2019). In other words, Tapa Brata can be interpreted as a process control human behaviors and attitude through with suppress worldly or profane desires with a good pattern. This is done in an effort to strengthen the spirituality of man who did it

Through tapa, the strength of the body is weakened, so that attitudes and feelings towards fellow humans change, people become more aware of the relativity of their existence (De, 1976). This is often done in conjunction with various types of fasting whose teachings are taught from generation to generation in Javanese people. Some typical fasts in Kejawen teachings such as mutih fasting (only eat plain rice and drink mineral water), ngeruh (only eat fruits and vegetables and drink mineral water), ngebleng (not eat and drink at least on 3 days), pati geni (alone in a quiet and dark room for 24 hours without light and fire), ngelowong (doesn't eat from 6 a.m until 6 p.m, and only sleep on 3 hours), ngrowot (replace rice with tubers), nganyep (eat all of foods without seasoning), ngidang (only eat fresh vegetables without cooking process like deer behavior), ngepel (only eat a fist of rice a day), ngasrep (only eat 3 spoons of rice and drink 3 sips of water), senin kemis (fasting on moday and Thursday), tapa jejeg (standing without sitting at least 12 hours), lelana (walk down the street from 12 p.m until 3 a.m), tapa kungkum (ascetic practice 
by bathing in the rivers), ngalong (sleep on the day and awake during night like a bat), and Weton fasting (Ariyanti, 2019). These fasts are carried out as an effort to distance themselves from life habits but without disturbing daily life, that it is aimed at practicing refinement and clarity of mind.

The process of Tapa Brata is practiced in several special levels, that a person who initiates Tapa Brata will have a consciousness that is still tied to his body, to the next level which will deepen towards spiritual or soul consciousness. This is in line with the division of the level of Tapa Brata spiritual practice, there is: tapa raga (physical ascetic) and tapa jiwa (mental ascetic) (Prabowo, Fakhrurrozi, \& Dewi, 2005). Tapa raga is done by reducing or even suppressing every bodily desire, such as sleeping, eating, drinking, sexual desire, and not fighting other people's actions. The object that is managed in the implementation of Tapa Brata at this stage is physical behavior related to the human body. And then continue to the next stage is tapa jiwa. At this stage the person who does Tapa Brata will come to an effort to hold back bad thoughts, such as suspicion, cheating, jealousy, and just keep the mind sincere and think with clarity of mind.

On Wedhatama scripture, there are also several explanations about the teachings of tapa brata, which are stated below:

Nulada laku utama/ tumraping wong tanah Jawi/ Wong Agung ing Ngeksiganda/ Panembahan Senapati / Kapati amarsudi / sudaning hawa lan nafsu/ pinesu Tapa Brata / tanapi ing siang ratri/ amamangun karyenak tyasing sasama//

Follow the best attitude/ toward all people of Java/ Great man from Ngeksiganda (Mataram)/ Penembahan Senapati/ who are very diligent/ to restrain lust/ by way of Tapa Brata / which is done day and night/ working to make peace and happiness in the heart of others

Some of the verses from the Wedhatama scripture can be understood that in Javanese society there is a prominent figure, namely Panembahan Senapati who is the founder of the Islamic Mataram kingdom. In this scripture, Panembahan Senapati is described as an expert in Tapa Brata practice in controlling lust, and himself likes to make happiness to others (Wibawa, 2013). This Tapa Brata is an attitude experienced by individuals or social groups, especially traditional Javanese society, by controlling their lust to achieve a positive change from the human psyche so that they can wisely face whatever reality occurs. This is in line with the 
idealized figure of Panembahan Senapati who was able to establish the Mataram kingdom from a small districts to become a great kingdom in Java due to his strong mental and mental practice. Panembahan name itself comes from the word manembah, or worship, which in the context of Javanese mysticism term manembah is synonymous with devotion to God (Widjayanti, 2015), the creator and source of all things.

In addition, in the life of Javanese society, the ideal is that a great human is a person who has depth of knowledge. In the Java community, has been strongly internalized that ngelmu iku kalakone kanthi laku (to be knowledgeable must be endured with effort), which may mean that knowledge can be gained by taking some effort (laku). This is in accordance with what is explained by R. Ng Ronggowarsito in Suluk Sopanalaya (Endraswara, 2012), which reads:

Rarasing ngelmu dolanan

Lamun ngelmu kang sejati

Kang tinuku Tapa Brata

Pae ngelmuning parecil

Ngacemil wae olih

Ngelmu baut nora kewut

Bedhel pedhot arantas

Tanpa tilas ora dadi

Jambe bleber miber lemper bebas

(Sopanalaya, Sinom, Verse 1)
Even though it's easy to know trivial knowledge

But better to know main knowledge

that obtained by Tapa Brata

Trivial knowledge is like knowledge of a child

that so easy to get

Not like main knowledge that can not be shaken

Trivial knowledge can broken to rubble

And just be nothing

In the verse in Suluk Sopanalaya, it is explained that in gaining knowledge it is not allowed to only know the trivial knowledge. The main knowledge can only be obtained by going through the process of Tapa Brata spiritual practice. In this case Tapa Brata becomes a medium that is believed to be in the Java community as a way to reach a depth of knowledge, not knowledge merely to know but real knowledge which really lived up through that spiritual practice. 
The spirituality of Tapa Brata practice can be said to be a process towards a subtle state of mind that is centered on the personality of each individual. This is based on the opinion that in order for a person to obtain a positive, constructive attitude to life, he must focus on his attention on the basis and meaning of his own personality (De, 1976). In this case, Base of spiritual life and religious should always be explored as a way of improving the positive elements in themselves to face the challenges of life. Therefore, Tapa Brata is not a form of passive attitude that does not produce, but is a mental practice with a purpose, that is the search for the essence of life.

The conditions for practicing Tapa Brata are not allowed to interfere with the passage of daily life, choosing a middle way between a state of satisfaction and a state of hunger (De, 1976). In other words, when doing Tapa Brata, it is not necessary to distance oneself from life, or make oneself an individual being, but to try to take a position in the middle by reducing the orientation towards the gratification of bodily desires. This position is a position of peacefulness to be in a harmony with whatever circumstances occur. Broadly, it can be said that through this Tapa Brata spiritual practice, an individual can more easily undergo adaptation to any condition. The basis of acceptance and openness is what makes a person who practices Tapa Brata able to be calm and wise in facing any condition.

\section{Tapa Brata as Efforts to Overcome Anxiety during the Pandemic COVID -19}

The study of religious philosophy basically has a broad range of studies consisting of visible and invisible realities. This visible reality is related to the empirical world, which is everything that can be achieved by human empirical ability. While the invisible reality is everything that is in the realm of metaphysics (Kasno, 2018), including in this case the existence of everything that cannot be reached through the human empirical senses, such as about essence, about possibilities, and various things that related to spirituality. Spirituality is an important dimension in the aspect of human religiosity. Religiosity here is related to the term religio, which is an attention to dynamic factors related to supernatural powers, ideas, and dreams obtained through an or various divine experiences (Carl G. Jung \& Afif, 2017). Meanwhile, spirituality is a part of it that is in the esoteric area. 
This esoteric area is often considered capable of connecting humans with various religious aspects, such as what is related to the divine essence and things that are beyond from symbols and physical senses. According to Schuon (1987), esoterically all beliefs and religions in the world have the same thing, that is the inner dimensions, and appear different because they are seen excoterically. Spirituality as part of an esoteric area is a necessity for all human beings without exception. This is like what Amsal Bakhtiar explains, that spiritual awareness will always be present and ontologically its existence cannot be denied in human life even by a communist or an atheist (Bakhtiar, 2007). Meanwhile, according to Barbara (MacDonald, 2001) spirituality is a process of human existence, in an effort to seek and find meaning of life. This opinion explains that spirituality is a force as well as a necessity that is always fundamental to filling the void in every human being to achieve the meaning of life.

During the COVID -19 pandemic, it has shown human helplessness in the face of an uncertain reality. Human anxiety over this which then encourages the flow of spiritual consciousness to reach the meaning of life. There is no way to escape this uncertainty, humans can only be respectful or open to all the possibilities that are so wide-spread (Kristiatmo, 2010). It is these impulses that then lead humans to be wise in understanding the meaning of life, trying to distance themselves from the routine of life and reaching new awareness of all possibilities in changing reality.

One realization of such inner impulse is through the Tapa Brata spiritual practice. Tapa Brata which is a form of spiritual practice of the Javanese wisdom that focuse on the inner attitude can be present as one of the solutions for the public to be carefully and wisely in dealing with the situation in the COVID -19 pandemic era which is so uncertain. As previously explained, that this Tapa Brata practice is done by taking a distance from previous habits. This is in line with the PSBB or PPKM policies which require a shift from outside routines to activities inside the home. In these conditions, Tapa Brata can be done as an effort to avoid anxiety, fear, and even boredom as a result of limiting social mobility. With Tapa Brata practice, people can more easily adapt to every condition, because basically spirituality itself is a form of self-disclosure to all realities that occur.

This is in line with recent discoveries regarding the importance of spirituality in maintaining mental stability and human immunity. Spirituality is not only correlated with visible aspects related to mentality, but also has a 
correlation with human physicality. This view is consistent with research conducted by Jayne Fernlster on the relationship between spirituality and its effects on cancer. And the conclusion is that the level of spirituality has an effect on the decreased need for pain treatment of cancer patients (Fernsler, Klemm, \& Miller, 1999). In the higher level of spiritual awareness, the patient can erode the pain he is experiencing. This is also in line with the level of human immunity to avoid disease and recovery from a disease. When someone who has a high level of spirituality will be able to easily adapt to certain illness conditions and help in the recovery phase (Prasetyo, 2016). Thus the fulfillment of spiritual needs has a correlation with the physiological aspects of the human being and helps in increasing the immunity of the human body.

\section{Conclusion}

The discussion in this qualitative research has some conclusions. That the conclusions of this research can be used as a reference for further research regarding the need for spirituality in the midst of the COVID19 pandemic era. The conclusion is that in the pandemic COVID-19, various changes occur immediately and massive worldwide. In Indonesia it can be identified in some government policy to tackling the flow of transmission of the Corona virus. Various policies were carried out, with the aim of suppressing the transmission of the Corona virus in Indonesian people, that the transmission rate is very high. This requires a change and diversion of various social habits that have been carried out in daily life, such as in work, schooling, and even in carrying out religious worship. The limitation on social mobility implemented by the government, from physical distancing, PSBB, to PKKM in early 2021, that demands the people to limit social interactions in the crowd, which previously became a daily life. Thus everyone is encouraged to reduce activities outside the home, and tend to be activities in the house. This condition then encourages the emergence of a sense of boredom in each everyone. Everyone can't wait to see when conditions will return to be normal, and it is in this state that the anxiety over the uncertain reality arises.

Anxiety arises from the realization when humans are dealing with an uncertain possibilities during this COVID-19 pandemic. The breath of modern society's fast life, high human mobility, and the growth of the economy has temporarily stopped due to the Corona virus pandemic. Awareness of the relativity of self amid an uncertain reality is then pushed to the realization 
that human beings can not to avoid themselves from the various possibilities that will occur in front of their. This uncertainty has been present and colored since the beginning of human civilization. In this awareness, every individual needs to take a distance from all his worldly routines to reflect on what is happening in life, this urge will lead to awareness of the needs of human spirituality. With spirituality, humans have openness and acceptance of everything that happens and able to deal with it wisely.

Tapa Brata is a spiritual practice that originates from the wisdom of Javanese tradition. Javanese society is a society known for its mystical teachings called Kejawen. The spiritual practice of Tapa Brata is an inner practice that is personal experiences. This spiritual practice done with several of fasting to strengthen inner self and clearing the mind. In this case the practice of Tapa Brata is not a structured ritual that demands religious symbols or special ceremonies, but Tapa Brata is a practice that focuses on inner openness. With this spiritual practice, every individual is able to experience acceptance of all the possibilities that can occur in life. In addition, with asceticism practice like Tapa Brata, indirectly also affect to physical aspect and increasing the body's immunity, because all realities that happens will be received like how its there

\section{References}

Ariyanti, M. (2019). KONSEP TIRAKAT PUASA KEJAWEN BAGI PENGHAYAT KEPERCAYAAN KEJAWEN. Seminar Internasional Riksa Bahasa.

Bakhtiar, A. (2007). Filsafat Agama: Wisata Pemikiran dan Kepercayaan Manusia. RajaGrafindo Persada.

Bakker, A. (2004). Metodologi penelitian filsafat. Kanisius.

De, J. (1976). Salah Satu Sikap Hidup Orang Jawa.

Dister, N. S. (1996). Pengalaman dan motivasi beragama.

Edelmann, R. J. (1992). Anxiety: Theory, research and intervention in clinical and health psychology. John Wiley \& Sons.

Endraswara, S. (2003). Falsafah Hidup Jawa.

Endraswara, S. (2011). Kebatinan Jawa dan jagad mistik kejawen.

Endraswara, S. (2012). Budaya Spiritual sebagai Wahana Pembentukan Karakter Bangsa. Makalah Sarasehan Budaya Spiritual.

Fernsler, J. I., Klemm, P., \& Miller, M. A. (1999). Spiritual well-being and demands of illness in people with colorectal cancer. Cancer Nursing, 22(2), 134-140. 
Fromm, E. (1996). Revolusi Harapan. IRCiSoD.

Gazalba, S. (1979). Kebudayaan sebagai ilmu. Djakarta: Pustaka Antara.

Hardiman, B. (2016). Heidegger dan Mistik Keseharian. Kepustakaan Populer Gramedia.

Ikbal, M. (2015). Memahami Agama Dengan Pendekatan Esoterik. Kalam, 9(1), 1-16.

Kasno, K. (2018). Filsafat Agama. Alpha.

Koentjaraningrat. (1984). Kebudayaan Jawa. Balai Pustaka.

Kristiatmo, T. (2010). Memahami Wahyu Kristiani melalui Heidegger. MELINTAS, 26(2), 193-217.

Laksono, P. M. (2009). Tradisi dalam struktur masyarakat Jawa: kerajaan dan pedesaan: alih-ubah model berpikir Jawa. Kepel Press.

MacDonald, B. H. (2001). Quality of life in cancer care: patients' experiences and nurses' contribution. European Journal of Oncology Nursing, 5(1), 32-41.

Maimun, A. (2015). Seyyed Hossein Nasr: Pergulatan Sains dan Spiritualitas Menuju Paradigma Kosmologi Alternatif. Yogyakarta: IRCiSoD.

Niels, M. (1980). Pribadi dan Masyarakat di Jawa.

Poedjawijatna, I. R. (1980). Pembimbing ke Alam Filsafat. Jakarta: PT.

Prabowo, H., Fakhrurrozi, M., \& Dewi, M. P. (2005). Pengembangan Kapasitas Manusia Dalam Tradisi Jawa. Proceeding, Seminar Nasional PESAT 2005. Universitas Gunadarma.

Prasetyo, A. (2016). Aspek spiritualitas sebagai elemen penting dalam kesehatan. Jurnal Kesehatan Al-Irsyad, 18-24.

Puspaningrat, S. (1996). Tata cara adat kirab pusaka Karaton Surakarta. Cendrawasih.

Schuon, F. (1987). Mencari Titik Temu Agama-Agama. Pustaka Firdaus.

Sutarti, T. (2019). Puasa Menurut Ajaran Agama Hindu (Perspektif Budaya Jawa). Widya Aksara, 24(2), 101-112.

Widjayanti, R. S. (2015). Perbandingan shalat dan laku manembah aliran kebatinan pangestu dan sumarah. Jurnal Studia Insania, 3(1), 63-78.

Yusuf, S. (2009). Mental Hygine: Terapi Psikopiritual untuk Hidup Sehat Berkualitas. Bandung: Maestro. 